\title{
Rebranding Technical Vocational Education and Training; Youth Education for Vocational Careers, Kenya
}

\author{
Dr. Kamau Kanyoro ${ }^{1}$, Chege Nancy ${ }^{2}$, Dr. Bironga Sophia ${ }^{3}$ \\ ${ }^{1}$ Lecturer University of Nairobi and Kenya Technical Teachers College [KTTC] \\ ${ }^{2}$ Lecturer Kenya Technical Teachers College [KTTC] \\ ${ }^{3}$ Senior Lecturer Kenya Technical Teachers College [KTTC]
}

\begin{abstract}
The aim of this paper is to revolutionize the approach of Technical and vocational training in Kenya, in regards to character and attitude change. The specific objective is to create awareness on the importance of Technical training in Developing countries. For any country to industrialize, as has been demonstrated by industrialized countries like Japan, Canada, Singapore and the USA, the key focus is technical and vocational training which produces technicians and artisan, the engine drivers of industrialization. This paper proposes a paradigm and mentality shift in Technical and vocational training approaches including; 1) Re-training of instructors/Trainers 2) use of pure practical approaches in training and integrating modern ICT approaches in training 3) Restrengthening of affective domain of learning in training with aim of producing technicians and artisans who are holistically trained but very strong in character.
\end{abstract}

Keywords: Affective, psychomotor, cognitive, andragogy, pedagogy, technology

\section{Introduction}

\subsection{Background information}

The preoccupation with teaching has..... Actually constrained the effectiveness of technical education and limited its abilities to meet society's demands.... We might say that we are now beginning to perceive that the purpose of education is learning .and we are beginning to realize that frequently, teaching interferes with learning." Teaching appears to threaten Technical education. Teaching frequently relies on lecturing and structured practical lessons where there is no relationship between what is taught and learnt (Biggs). There is no room for instructors/trainers and learners/ trainees to be creative since they are bound to complete the syllabus which sometimes have content that is obsolete. Taking an analogy of the builder and architect in the Israel the architect is also the builder, likewise designers of the technical and vocational curriculum should also be the implementers. Teaching that promotes and maintains dependency stifles creativity and innovation. Knowledge in technical and vocational education should be tacit knowledge developed and documented in the process of performing a skill. Scientific critique is the essence of scientific training method which should the channel of transferring technical information.

\section{Global Context in Technical and Vocational Education}

Nothing in life exists alone or in isolation, everything is connected to another. This fundamental principal of life is well expressed by the dynamic shifts happening in the earth today. The world is in a state of massive change and revolution. The 21 st century has provided a basic framework in the advancement of knowledge and technological changes. All the sectors of life i.e. social, political and economic pillars have experienced tremendous changes in the recent times. Social traditional stable institutions like the family have been shaken to the core, global political architecture has also drastically changed, economic and financial institutions like the IMF and world bank have also felt the impact of globalization .Never in the history of the planet has the world experienced such an unprecedented changes as it is happening in the neo-times. With the understanding of these changes in the modern times both at global and national context, investing in YOUTH EDUCATION is the ultimate design for the future.

Education is the basic tool for building and crafting strong philosophies in social, political and economic advance of any country. Nations which have invested immensely in the development of its youth have continued to reap maximum benefits in terms of national productivity and development. All levels of training from pre-school [nursery], primary, secondary, vocational/tertiary institutions and universities must be coherently harmonized to bridge knowledge and skill gaps which will minimize overproduction of university graduate trainees but few artisans and technicians who are trained in vocational and technical institutes and are very pivotal for any country to industrialize.

For a structured harmony to be achieved in promoting vocational technical education and training there must be political goodwill to formulate policies in place that will govern technical and vocational colleges, government special economic input must be there to retrain technical instructors with modern knowledge, skills and attitude, upgrade existing colleges and where applicable build new ones. Paradigm and mentality shift trainings ought to be conducted at the basic level of trainings especially in primary and secondary schools. This will help to adjust the thinking system of our young people in regards to their perception towards joining vocational and technical institutions. There has been a wrong over emphasis of pushing students to perform so as to join university, whereby learners who don't join university are branded failures by 


\section{International Journal of Science and Research (IJSR) \\ ISSN (Online): 2319-7064 \\ Index Copernicus Value (2013): 6.14 | Impact Factor (2015): 6.391}

the system and some of them can make very good artisans and technicians given an opportunity and with the right ATTITUDE.

In rebranding technical and vocational training in Kenya and by extension in Africa, the following training units should be integrated in the curriculum to make it relevant, effective, and efficient;

\subsection{ICT Integration in Vocational and Technical Training}

Effective usage of ICT for both learning and management purposes is needed. There is increasing use of ICT for both administrative and teaching purposes. This helps to improve and transform learning, teaching, and leadership in schools, colleges and lifelong learning. For example, World Space is providing one broadcast channel satellite that can broadcast audio programmes and transmit multimedia information, and it can download text, video, audio, and graphics to a radio. Files can then be sent to an attached computer. Distance education techniques are used to offer vocational training, with the television being the main mode of delivery.

\subsubsection{Learning Management System - Open Source}

A solution that can be cheaply implemented within vocational training systems and utilizes open source licensing meaning its free for download and use is a solution such Moodle (https://moodle.org/) that has revolutionized learning institutions all over the world.

This kind of software amongst many others like Linux operating would enable vocational training institutions offer ICT integrated programs on minimal budgets due to the open source licensing.

Development is primarily a learning process one group cannot develop another the only type of development ossible is self development R.L. Ackoff, 1990.

\subsubsection{ICT for programme support}

The use of ICTs for administrative purposes, career education and guidance, labor market information, placement of graduates, information search and retrieval, communication purposes and programme design and development.

MIS (Management Information System) is essentially a computer program that can store important pieces of information. Since all the data are stored electronically, MIS facilitates the collection and analysis of these data. The data can be easily accessible to instructors and administrators, which will save time for routine tasks. There are several types of student data that can be stored: attendance, assessment, report writing, timetable, finance, communication, allocation of classroom and laboratory facilities, budgeting, cash flow etc.

\subsubsection{ICT for career education and guidance}

ICT support to Career Education and Guidance in technical and vocational training includes; 1) Storing large amounts of information in a range of formats which acts as repository for other students.2) Searching for and retrieving information quickly and accurately. This may include audio presentations and practical video presentations.3) Matching information to suit individual preferences in order to consider individual to enhance innovations and invention (creativity) 4) Documenting and recording tacit knowledge in technical operations with the aim of sharing it out with the new technicians in the industry.5) Simulating work environment and updating information quickly.6) Providing a mechanism for sharing and communicating information

\subsubsection{Using ICT to provide Labor Market Information}

In an economy where human capital has become a critical element in the production of goods and services, easily accessible and up-to-date labor market information (LMI) must be available to students. ICTs are increasingly used to disseminate LMI

\subsubsection{Using ICT for placement of vocational trained graduates}

ICT is revolutionizing employee recruitment and job search, many countries, including Australia, Canada, and the United States have created online national job bank where employers can post vacancies, and job seekers can search for jobs by occupational categories, average earnings, and geographical location. These free services have considerably reduced the time needed for matching employers and employees.

\subsubsection{Using ICT for information search and retrieval}

Manuals are conveniently stored on various CD-ROMs so that they are readily accessible. In this information age the ability to retrieve and use information in form of electronic text, sound, graphics, and video is becoming an essential skill. Identified below are critical skills related to information retrieval: Ability to conduct the Internet search, ability to restructure information, ability to assess the quality of information, ability to assess the validity and authenticity of material, ability to assess the quality of information, ability to select the most appropriate source of information and finally ability to download and save information.

All education institutions in developed countries host digital library catalogue systems where teachers and learners can perform a computer-based search. Searches can be done on a number of variables such as authors, subject, titles, and keywords and can use searching limits such as the date or year published language, and material type. Educational institutions can also purchase licenses to electronic databases that contain bibliographic information for books, articles, and journals. These databases span several different disciplines, such as engineering, science, social sciences, and humanities.

\subsubsection{Using ICT for study-at-home programmes and for informal skills(Vocational) development}

Home-study programmes are available in a wide range of trades and professions, from auto mechanic to accounting. Delivering these programmes has traditionally relied heavily on print-based materials; however, in recent years more ICTs have been used to deliver programmes. For example, Education Direct is a "Train at Home" Canadian correspondence school offering TVET programmes in over 


\section{International Journal of Science and Research (IJSR) \\ ISSN (Online): 2319-7064 \\ Index Copernicus Value (2013): 6.14 | Impact Factor (2015): 6.391}

55 occupations to Canadians. Education Direct (www.edudirect-canada.com) is fully accredited by Canadian Education and Training Accreditation Commission (CETAC).

\subsubsection{Using ICT for virtual internship for Vocational Training}

Virtual internship is defined as an activity that involves the use of the ICT supported environment where students interact with each other and with companies, independent of time and space and across traditional geographical boundaries. In this environment, effective communications are created between students, faculty, and company representatives, in order to carry out a specific and meaningful work-based activity that fits within the student's compulsory education environment.

\section{Life skills Integration in Vocational and Technical Training}

Dr.Martin Luther kinges jnr. said "educating a human in the mind without educating him in the morals/heart is educating a monster in the society"

General Munroe: "leadership is a combination of character and skills [strategy], but if a leader has to do without one, let him do without skills/strategy, for character is the strategy "

The world is deficient of morally upright trained personnel. Employers all over the world are expressing dissatisfaction with the current training systems which are producing skilled personnel who have no moral values, can't be relied upon ,and no character and integrity to carry out a given task without stealing and corrupting their way through. Life skills virtues and values like integrity, honesty, faithfulness and sincerity can't necessarily be taught in a classroom environment but are imparted and transferred and are well captured in the normalcy of life in everyday operations.

Life skills training promotion should be highly propagated in vocational technical training starting with the trainers and instructors who are the channels and structures through which values and vices of life are transferred and imparted. It is imperative to note that students become what their leaders and teachers are. In the three domains of learning, i.e. is cognitive [knowledge/head],psychomotor[skills/hands ], and affective[attitude/heart] little has been done on the affective/heart domain which is and should be the foundation of any training. In regards to rebranding technical and vocational training, affective/heart domain should be the major focus to help foster and develop character and build correct attitudes which are the containers that hold knowledge and skills. Life skill training should be approached from a platform of values and character transfer as opposed to the traditional method of teaching about values in an approach of exam oriented. There has been a distortion and misconception about life skills in our trainings where learners are taught life skills as an examinable subject, where learners memorize concepts but little was achieved in them in terms of character and behavioral change.
To counter terrorism and youth radicalization which targets youths in schools and colleges, prudent measures ought to be put in place to save the youth from extremistse ${ }^{\text {ee }}$ religious beliefs and philosophies. Global terrorist architecture has changed in the modern times with very intelligent youths in schools and colleges joining the extremist groups and organization, for the recruiters have identified a gap among the youths. Basic security trainings should be introduced in the vocational technical colleges to equip the youth with knowledge and skills on security matters and create awareness on the impact and devastating effect of terrorism in the society. Countries like Germany and Rwanda have integrated basic security trainings to their youth before joining colleges and universities and such a model can be implemented in our vocational training colleges.

\section{Role of Science in Vocational Training}

Vocational education in Kenya is an opportunity for success and for young people to find passion in the world of work and pursue that passion. Students engaged in the vocational training bring one hundred per cent of them and enjoy a lot of fun. Success sometimes means connection and engagement and vocational education offers all that.

In Kenya, Vocational training is highly confined to TVET institutions. Industrial attachments are not very much practical. This spell a danger to the institutions in that the training could easily revert to scientific theories. Moreover, the institutions are not very well equipped. Science subjects become a very common way of explaining principles of technology rather than practically doing it. The teachers in these institutions must be vast in the subject areas. But teaching of science should not be considered as a major issue in the institutions. More emphasis should be laid on hands on activities. Students who might not have performed so well in the science subjects, in the formal schools, might do very well in the technical subjects. There are some students who understand what they do and can improve on products as they function. These students do not care about the explanation of why it is functioning but how it is functioning. To them, technology creates science. They create technology then science should explain why it is functioning.

This does not mean that can science should be delinked from technology. The two are intertwined. To explain this one can borrow metaphor from Biology. There is a kind of double helix of DNA. One strand of the helix is science; the other is technology. The two are inextricably linked and neither can advance in the long run without advances in other. It is therefore very important to teach basic scientific skills in the TVET institutions to equip the students with the discipline of paying attention to details. Many of the scientific principles were discovered accidentally by scientists who could not ignore some minor details they could otherwise easily ignore. Our young people should therefore be able to account for any form of out comes in their places of work.

Someone once said that ,technology transfer is a contact sport." In industry it works best by bringing together the scientists, engineers and product developers. This means that once the TVET institutions products are in the field, they 


\section{International Journal of Science and Research (IJSR) \\ ISSN (Online): 2319-7064 \\ Index Copernicus Value (2013): 6.14 | Impact Factor (2015): 6.391}

would work closely with other professionals. It is important to develop their knowledge in science to ensure they can communicate and corroborate well for maximum impact. What should go into the curriculum should be well researched so that the very essence of having the TVET institutions should not be watered down. Emphases should also be from the hand on activities to the scientific principle and not scientific theories to practical.

Products of TVET institutions should also be given avenues to mentor the young in their ladder. To do this they require a vast base knowledge in the areas of their specialization. This means that some of them need to deepen in the scientific skills. TVET institutions therefore have a challenge to restructure their program to cater for this. In Kenya, today very few graduates have these avenues to improve their positions. In order for the country to achieve vision 2030, they must be encouraged to further their studies by systems that provide wider avenues all the way to the degree level.

The country needs to prioritize Technical Training and Vocational Educations if it has to overcome youth unemployment and achieve vision 2030. Singapore had a low unemployment rate of below six per cent in 2011. This was lower than most of the developed countries which ranged from 8.3 to 21 per cent. They attributed this to their Technical training and Vocational Education. Kenya needs to expand Technical Training and Vocational Education to enable a huge population of the kids who do not qualify to join secondary school and universities. Since this about imparting skills, our program should be improve to run parallel with formal learn to provide that much needed alternative. The rate of unemployment among the youth is brought about largely by the population that is not unemployable.

\section{Conclusion -Way Forward}

To achieve sustainable changes and output in rebranding technical and vocational training among the youth in Kenya the following practical steps must be implemented;

1) Redesigning the three [3] domains of learning where a lot of emphasis should be the affective domain that deals with attitude and character. Affective domain should be the foundation upon which the other two domains i.e. cognitive and psychomotor are built. This in turn should be followed by retraining the trainers and instructors who should be men and women of outstanding morals since they will be expected to transfer the same to the learners.

2) Design and implementation of technical education policies should be based on action research, where the researcher is given an opportunity to implement his/her own research. This will save time and cost in writing many research papers with recommendations that are never acted upon.

3) Paradigm and mentality shift trainings must be conducted in primary and secondary schools to promote and sensitize young learners on the importance of technical education and tap gifted youth with special talents in technical and artistic fields, guide and counsel them in the right direction. Learners must be made to understand that not joining university is not failure but there are other avenues and opportunities in life and specifically technical field.

4) Curriculum designers should also be the implementers. Technical instructors find it difficult to train and teach concepts that lack their input, since they were never involved from the onset.

\section{References}

[1] Ackoff, R.L. 1990. Ackoffes fables. Very short stories with very sharp points - on development. Systems Practice, 3:3-6

[2] Kariku kimani[ 2015]-science and vocational training in kenya

[3] Keep e.[1999]-TVET-technical vocational education training in developing countries

[4] Neuman Ziderman[19991]-vocational schools in Israel

[5] Patrinos [2004] returns to invest in education Tilak [2003]-vocational education and training in Asia

\section{Author Profile}

Dr. Kamau Kanyoro is a lecturer at University of Nairobi, currently a visiting lecturer at Kenya Technical Trainers College (KTTC). He is also a psychologist consultant and has obtained Doctorate in education management and PHD in psychology from America military university.

Nancy Chege is a senior lecturer at Kenya Technical Trainers College (KTTC). She obtained her Msc in Agriculture Education from Egerton University in Kenya and Msc research methods from JKUAT University, Kenya. She is currently a PHD fellow at Egerton University.

Dr. Bironga Sophia is a senior lecturer at Kenya Technical Teachers College [KTTC] and a visiting lecturer at Kisii University. 